\title{
Why some countries are immune from the resource curse: The role of economic norms
}

\author{
S. Erdem Aytaç ${ }^{a^{*}}$, Michael Mousseau ${ }^{\mathrm{b}}$ and Ömer Faruk Örsün ${ }^{\mathrm{c}}$ \\ ${ }^{a}$ Department of Political Science, Yale University, New Haven, USA; ${ }^{b}$ Department of \\ Political Science, University of Central Florida, Orlando, USA; ${ }^{c}$ Department of \\ International Relations, Koç University, Istanbul, Turkey
}

(Received 11 February 2014; accepted 17 August 2014)

\begin{abstract}
The political resource curse - the detrimental effect of natural resource dependence on democracy - is a well-established correlate of authoritarianism. A long-standing puzzle, however, is why some countries seem to be immune from it. We address this issue systematically by distinguishing two kinds of economies: contract-intensive, where individuals normally obtain their incomes in the marketplace; and clientelist, where individuals normally obtain their incomes in groups that compete over state rents. We theorize that the institutionalized patronage opportunities in clientelist economies are an important precondition for the resource curse, and that nations with contract-intensive economies are immune from it. Analysis of 150 countries from 1973 to 2000 yields robust support for this view. By introducing clientelist economy as a prerequisite for the resource curse, this study offers an important advance in understanding how nations democratize.
\end{abstract}

Keywords: resource curse; democracy; clientelism; economic norms; political economy

\section{Introduction}

While many studies have confirmed the detrimental effect of natural resource dependence on democratic governance, there is little consensus on the causes of the "resource curse", and more recent evidence suggests it may not even exist. The most-often cited causal mechanism is the "rentier state" hypothesis, first articulated by Hussein Mahdavy, which posits that resource-rich regimes tax less and spend more than other regimes, enabling them to resist, buy off, or more effectively repress opponents; thus destabilizing democracy and stabilizing autocracy. ${ }^{1}$ Yet, systematic investigation of this causal path is difficult, and a more recent study using fixed-effects suggests that the resource curse may be spurious, with some

\footnotetext{
*Corresponding author. Email: erdem.aytac@yale.edu
} 
time-invariant factor possibly accounting for the association of regime type with resource dependence. ${ }^{2}$

Also worrisome for the rentier state hypothesis is the abundance of evidence that some countries seem to be immune from the resource curse. There is nothing in the rentier state hypothesis that accounts for why some countries, like Norway, have not transformed into a rentier state, like Saudi Arabia. Similarly, Goldberg et al. have pointed out the historical experiences of Australia, Canada, Great Britain, and the United States (US), which have displayed no symptoms of the political resource curse despite significant natural resource wealth. ${ }^{3}$ They also note that while some suggest that the rentier state hypothesis only applies to the developing world below a certain income threshold, "the mechanisms adduced to explain the correlation are independent of income and therefore ought to still be at work". 4

Observing that extant studies offer an insight only on the average effect of natural resources on regime type, scholars have recently started to investigate whether the resource curse is a conditional one. ${ }^{5}$ Michael L. Ross acknowledges that "the ultimate effect of oil wealth [on democracy] will vary under different conditions and identifying these conditions lies at the frontier of research on this problem". 6 This article presents such an effort by introducing an important modification to rentier state theory, offering a novel and precise explanation for the conditional effects of the resource curse, while additionally accounting for the immunity of some countries to it, with supporting empirical evidence. ${ }^{7}$

We draw on economic norms theory to show how clientelistic economic norms that are present in most developing countries may be the crucial lynchpin linking natural resource dependence with the failure of democratic institutions. ${ }^{8}$ When a clientelist economy is endowed with resource rents, as happened in Iran, Libya, and Saudi Arabia, those who control the state are positioned to emerge as the largest patron in the nation. This influence can destabilize nascent democratic institutions and allow the solidification of autocratic ones. In contrast, when a nation has a strong culture of contracting before it becomes endowed with resource rents, prevailing interests in norms of government impartiality in the enforcement of contracts and equal rights in market access as well as a lack of patronage networks effectively block any attempt by incumbents to use rents for political patronage. In this way, we offer an important caveat to rentier state theory: the resource curse is expected to be present only in societies which lack extensive contracting.

Prior research has shown that nations with contract-intensive economies are immune to the civil conflict-inducing aspects of resource rents. ${ }^{9}$ Analyses here of 150 countries from 1973 to 2000 corroborate that nations with contract-intensive economies are immune to the political resource curse as well. However, among nations with clientelist, or contract-poor, economies increases in resource dependence have negative repercussions on democratic governance. ${ }^{10}$ Therefore, we elucidate when and how the resource curse develops, and at the same time expose the antidote: the demise of hierarchical patronage networks and the transition to equitable contract-intensive economy. This result has direct implications for 
understanding how wealth causes democracy and the politics of the Middle East, where extreme levels of autocracy, conflict, and resource curse may all be rooted in the clientelist economies of the region.

\section{The resource curse}

While the discussion of the economic consequences of natural resource dependence has a relatively long history in the relevant literature, ${ }^{11}$ the systematic investigation of the political resource curse began with the highly-influential article of Ross, who reported that "the oil-impedes-democracy claim is both valid and statistically robust; in other words, oil does hurt democracy". ${ }^{12}$ Most empirical studies have corroborated this detrimental effect of natural resource dependence on political regimes, ${ }^{13}$ while Dunning proposed that the effect of natural resources on regime type is conditional on the distribution of income. ${ }^{14}$ Most recently, Haber and Menaldo contend that there is little evidence for the resource curse, suggesting that all previous studies may be affected by omitted-variable bias, with some timeinvariant factor accounting for both resource dependence and regime type. ${ }^{15}$ As a response, Andersen and Ross argue that Haber and Menaldo's findings are driven by two implausible assumptions that (1) resource wealth has an immediate effect on a country's regime type, and (2) the relationship between these two variables has not changed over the last 200 years. ${ }^{16}$ By modifying these assumptions, they are able to show that Haber and Menaldo's core findings are uncorroborated.

The literature identifies three main mechanisms through which natural resource rents may exert a detrimental effect on democratic governance. ${ }^{17}$ First, as natural resource rents increase to constitute a significant share of a government's revenues, the state is effectively relieved of the need to tax the population. This "taxation effect" is said to reduce citizens' interest in government accountability, and thus democracy. The second mechanism has been called the "spending effect": governments that fund themselves through natural resource rents will have more resources for buying-off the opposition. The third mechanism, the "repression effect", suggests that resource rents give governments more resources for repressing the opposition. These effects are not mutually exclusive; all could be at work simultaneously.

Perhaps the greatest challenge to the resource curse hypothesis comes from the observation that none of the proposed causal arguments offer an explanation for the abundant anecdotal evidence that the resource curse does not apply to consolidated democracies or rich countries. ${ }^{18}$ For instance, Norway is the world's seventhlargest oil and second-largest natural gas exporter as of 2012. Its economy is highly dependent on the petroleum sector, which accounts for the largest portion of export revenues and about a fifth of government revenues. ${ }^{19}$ Yet, there has been no deterioration in the country's democratic institutions since the discovery of abundant energy resources almost three decades ago. The historical experiences of countries such as the US, Canada, Australia, and Great Britain defy the conventional wisdom about the resource curse as well. ${ }^{20}$ 
Despite the ubiquity of the observation that some countries are immune to the resource curse, little attention has been given to address this "anomaly", or to develop a conditional theory of the resource curse. An exception is the study of Dunning, who identified how a low level of income inequality may exacerbate the resource curse. ${ }^{21}$ Dunning's intuition is that since the demand for redistribution should be lower in more equal societies compared to more unequal ones, in the former rents could be more effectively deployed to buy-off or repress the opposition. One potential problem with this argument is the assumption that there are no exogenous constraints on the government to buy-off or repress the opposition: if we consider the cases of Norway and Russia as stylized examples, the theory assumes that the strategy of buying-off or repressing the opposition is equally feasible in both countries. Such an assumption would not be plausible to most observers since the socioeconomic structures of societies place different constraints on which strategies are feasible to leaders.

In short, with the exception of Dunning, no study in the literature puts forward a conditional theory of the resource curse, and the immunity of some countries to it is left unexplained. We provide an explanation by drawing on the economic norms theory in the following section.

\section{Economic norms theory and the resource curse}

It is well-documented that through most of civilization - and in most developing countries today - economies have been integrated less with markets than with personalized forms of exchange, such as favours exchanged among friends and family linked with groups. ${ }^{22}$ This form of political economy is often referred to as clientelism. ${ }^{23}$ While the familiar approach towards clientelism has been to consider it a "holdover from traditional societies" that would cease to exist upon the transition to modernity, by the 1970 s and 1980 s it became clear that clientelistic exchange was not disappearing in many countries. ${ }^{24} \mathrm{~A}$ clientelist economy must be contrasted with a contract-intensive economy, which prevails in Western Europe, Scandinavia, North America, and some countries of the Pacific Rim. There, individuals normally obtain their incomes from strangers located in a market in the form of contracts dependent on third-party enforcement. ${ }^{25}$

According to economic norms theory, contractualist and clientelist economies differ primarily in the manner in which most individuals obtain and hold their economic securities. Where incomes and securities are normally held in contracts, there is widespread dependency on a third party, namely the government, for the enforcement of contracts. Since no one can automatically trust the contractual commitments of strangers, as exogenous factors cause markets to overtake traditional clientelist forms of economic integration in a nation, individuals develop interest in the state acting as a reliable, impartial, and credible enforcer of contracts. They also develop an interest in the state protecting everyone's freedom to contract equally, for the simple reason that the larger the number of strangers who are free to contract, the greater one's own opportunities in the marketplace. Since the 
impartiality of the state's enforcement of contracts must be recognized as credible by all those in the market, the regular turnover of government through free and fair elections surfaced as the best way to preserve the state's new-found role of market referee.

A clientelist economy, in contrast, is conducive to the emergence of an authoritarian regime as patronage networks yield leaders a loyal following of clients who are economically dependent on them. Clients are loyal to persons, not to the state, and they want their leaders to be linked to the state for the purposes of undermining its impartiality with corrupt linkages that give privileged access to state rents. Many nations with clientelist economies frequently experiment with democracy, often under pressure from the contractualist democracies, but a clientelist democracy is more often than not illiberal, corrupt and unstable. ${ }^{26}$ Consistent with this prediction, every case of major democratic reversal in our data from 1973 to 2000 occurred in a nation with a clientelist economy. ${ }^{27}$

Accordingly, it is straightforward to see how natural resource wealth could be detrimental for democracy in clientelist but not contractualist economies. In a clientelist economy, economic competition is political competition, so groups that prevail in controlling the state have strong incentives to divert natural resource rents to their supporters in exchange for loyalty. Clientelist institutionalization means that patronage networks are well-established: with a rise in resource rents many key actors will strategically switch their loyalty to patrons who are linked to state coffers. In addition to this "spending" effect, there is also the "repression" effect: as the increased revenues can be devoted to distributing rents to larger numbers of groups, newly-included clients and their patrons readily help in the repression and discrimination of remaining out-groups. This account is compatible with the observation of Ross that the resource curse manifests itself after the late 1970s when the control of oil rents shifted from multinational firms to governments as a result of a wave of nationalizations. ${ }^{28}$

In a contract-intensive economy, in contrast, the lack of existing patronage channels means that there are few avenues with which a regime can divert rents. Moreover, the politically-motivated distribution of rents would disrupt the working of the contract-intensive economy (from which a considerable portion of the society is benefiting) by weakening the rule of law, so that there would be significant opposition towards patronage attempts purely due to collective interest. As such, the conditions that are responsible for the resource curse simply do not exist in a contract-intensive economy. Some patronage might frequently occur in these kinds of economies, but its adverse effects are contained as most members of the electorate, habitually obtaining their incomes in the market, insist on the democratic rule of law for the impartial enforcement of contracts.

A brief discussion on the experience of Norway and Russia is useful to illustrate the mechanisms that we propose are at work. ${ }^{29}$ Norway became a producer of oil and natural gas from 1973 onwards, and today its economy is heavily dependent on the petroleum sector. ${ }^{30}$ This dominance of natural resource rents in the Norwegian economy, however, did not prevent the country from maintaining its highly 
democratic regime after the oil boom, contrary to the resource curse hypothesis. From the perspective of economic norms theory the observation that Norway has been immune to the resource curse is expected. Oil production in Norway did not provide net income until the early 1980s, and by that time the country had a contract-intensive political economy. ${ }^{31}$ Accordingly, by the time significant resource rents began to flow into the state treasury, Norwegians had already direct interest in their government enforcing contracts impartially, reliably, and efficiently. In such a context we would expect politically-motivated distribution of rents, and a subsequent deterioration in democratic governance, to be highly unlikely.

Scholarly accounts on the management of Norwegian oil rents provide empirical support for this interpretation. Mehlum et al. note that oil rents in Norway stimulated productive forces rather than grabber activities as a result of strong rule of law, property rights, and a well-functioning state bureaucracy. ${ }^{32}$ Additionally, all the proceeds from the petroleum sector to the state enter into the Norwegian Petroleum Fund, which renders the sector's contribution to public finances transparent. Eifert et al. emphasize that the mechanisms to distribute the proceeds should be part of a transparent budget process to prevent rent-seeking behaviour, and this is exactly what is observed in Norway. ${ }^{33}$ They also note that "Norway has been successful in using its highly consensus-oriented ... institutions as well as the involvement of interest groups representing business and labor to reconcile competing claims over oil rents with long-term objectives and stabilization goals". ${ }^{34}$

Like Norway, Russia is an extremely rich country in natural energy resources. As of 2011, Russia was the world's leading oil producer and the second-largest producer of natural gas. ${ }^{35}$ Thanks to rising energy prices during the last decade, the Russian government's revenues from the energy sector increased almost tenfold (in US dollars) between 2003 and 2008, making up close to a half of federal budget revenues, while fuels and mining products constituted about $70 \%$ of all merchandise exports by value. ${ }^{36}$

While Russia could be considered quite similar to Norway in terms of its exceptional resource endowment, it cannot be more distant in terms of political regime. Steven Fish designates the Russian polity effectively as an oligarchy where electoral fraud, monitoring, and harassment of regime opponents are common, and there is a strict state control over public communication and sources of information in the media. ${ }^{37}$ Similarly, Lucan Way notes that while the period of 1994 to 1999 could be characterized as a case of "moderate executive control" in Russia, since the early 2000 s the country has become increasingly autocratic. ${ }^{38}$ Thus, it is not surprising that while Russia was considered as "Partly Free" after the demise of the Soviet Union in 1991, it slipped to the category of "Not Free" after 2003 in the country ratings of the Freedom House. ${ }^{39}$

Again, economic norms theory offers a coherent explanation why natural resource windfalls were partly responsible for Russia's trajectory towards oligarchy from the early 2000s onwards. By the time substantial rents started to 
accrue to the Russian government's treasury, the country had a clientelist political economy where patronage networks served as mechanisms for exchange of loyalty of public officials, governors and mayors to the regime in return for resources to sustain their own networks of clients and followers. ${ }^{40}$ Before the 2000 s, such networks were of limited scope due to the scarcity of funds, but the commodity boom of the 2000s provided the Putin government with the necessary resources to expand patronage networks and establish the regime's dominance in every aspect of political life. While the increase in overall employment was just $4.7 \%$ between 2000 and 2010, the number of government officials grew at a startling rate of $22.7 \%{ }^{41} \mathrm{~A}$ broad expansion of power of the executive branch at the expense of any independent sources of power ensued, together with a significant increase in public spending. ${ }^{42}$

One of the leading accounts of Russia's slide towards authoritarianism lends support for the mechanisms predicted by economic norms theory. Fish argues that there are two links between natural resource endowment and decreasing openness of a political regime. ${ }^{43}$ First, the availability of resource rents in a country like Russia increases corruption. He notes that "in any resource-abundant country that does not have a highly developed, long-standing system of laws and effective agencies of law enforcement in place prior to the discovery and exploitation of the resources, the very reason for holding office may be nothing more (or less) than robbery". ${ }^{44}$ These very characteristics mentioned by Fish are the sine qua non of a clientelistic political economy. Corruption, in turn, engenders perverse incentives to enter politics, damages the legitimacy of the regime, and increases the attractiveness of political closure by the elites. Indeed, corruption is endemic in today's Russia: the country ranks 133rd among 174 countries in the Corruption Perception Index 2012 of Transparency International, ${ }^{45}$ and it has been suggested that the sharp expansion of resource rents during the last decade might be responsible for pervasive corruption. ${ }^{46}$

Second, and perhaps more importantly, natural resource rents might have had a deleterious effect on democracy in Russia by promoting statism in the economy. ${ }^{47}$ A high level of statism in the economy and the concomitant patronage resources of the state destroyed the socioeconomic bases required for the development of independent social and political organizations, which in turn inhibited open politics and democratization. Fish presents a handful of examples in this direction including the take-overs of the formerly main private television company (NTV) and leading public opinion firm (ARCSPO) by the state, control of the main trade union of the country (FITUR), and prohibition of the formation of others. ${ }^{48}$ Again, it would be useful to contrast this picture with the case of Norway where the state also has had extensive involvement in key sectors of the economy. Thus, while significant state involvement in the economy does not seem to be a concern for democracy per se, in a clientelistic political economy such as Russia it is a recipe for authoritarianism, since the state in such an environment becomes a vehicle for building patronage networks to dominate the political sphere. 


\section{Testing the conditionality of the resource curse}

In this section we outline our empirical strategy for testing whether the resource curse is conditional on the political economy type of a country. After presenting the data employed, we describe our estimation technique and discuss the results.

\section{Data}

We operationalize our dependent variable using the "Freedom in the World" dataset of the Freedom House. ${ }^{49}$ This dataset is widely used in the relevant literature, and it has the advantage of measuring individual rights as well as the quality of elections. ${ }^{50}$ We combine the Political Rights and Civil Liberties indices of the dataset and transform the combined index such that it lies between 0 and 100, with 100 corresponding to the most democratic regime.

We use a dataset that is produced by the World Bank to measure the extent to which countries' income is derived from natural resource extraction. ${ }^{51}$ This value of natural resource depletion is calculated as the net profit per unit of natural resource (sales price minus extraction cost) times the amount of resource extracted. Next, this value is expressed as the percentage of Gross National Income (GNI) annually. ${ }^{52}$ This measure gives a more comprehensive picture of the importance of natural resource rents within a country's economy compared to other measures related to exports. Although the original data source includes variables that indicate the share of a country's GNI derived from the depletion of energy sources (crude oil, natural gas, and coal) as well as from other mineral resources (copper, gold, iron, etc.), we limit our examination to energy rents, following the latest contributions to the literature. ${ }^{53}$ From a theoretical perspective it has been noted that while "petro-states" (major oil-exporting states) have many characteristics in common with mineral-exporting states, the nature of oil rents make them unique: "[Petro-states] are rentier states par excellence: not only does petroleum provide exceptionally high levels of rents over a long period of time, but it also facilitates international borrowing, thereby perpetuating the capacity to live beyond their means". 54 Thus, oil rents are of significant importance for the rentier state hypothesis. We smooth extreme values by log-transforming the measure, and call the variable Energy Rents.

In order to construct our key explanatory variable, the contract-intensity of an economy, we draw on direct data on contracting in life insurance securities. Not all contracts cause dependency on the state; many do not rely on third-party enforcement. Instead, they rely on personal trust among contractees and fear of personal sanction in the event of violation of this trust. Life insurance contracts are unique in that policyholders must be deceased before insurers can fulfil their contractual obligation. This means policyholders must have some reasonable expectation that if the insurance company fails to meet its obligations, beneficiaries can rely on the state to enforce the contract. In short, a society with high levels 
of life insurance contracting must have substantial numbers of people who have an interest in their state acting as a capable, efficient, and impartial arbiter of contracts - the causal mechanism at the core of economic norms theory. In prior studies, life insurance data have been used to corroborate powerful roles for contractualist economy in promoting peace and human rights within nations, and reducing conflict among them. ${ }^{55}$

Direct data on life insurance contracts in force (in constant US dollars) have been compiled under the auspices of the World Bank, with coverage for about one-third of nations in the 1980s and 1990s, and a smaller number of nations covered over the entire time span of 1960 to $2000 .^{56}$ We treat missing data as reflecting clientelist economy, because we have reason to believe that governments of nations with contractualist economies are more likely than clientelist ones to produce data. When missing data are not random in some known way, it is best to use this knowledge in estimating missing values. Governments of contractualist societies have comparatively stronger incentives of delivering the public good of market growth, and collecting, analysing, and disseminating economic data helps in the development of successful growth policies. In addition, these states also have the bureaucratic capacity, demanded by voters for the enforcement of contracts, to collect and disseminate data. In the modern era, clientelist regimes have the opposite incentives of avoiding reporting data of any kind since their primary strategy of survival is the distribution of state funds to supporters, often illegally. Thus, any transparent accounting of how they handle state rents can have adverse political consequences.

To facilitate the treatment of missing data the variable was dichotomized at the median, with nation-years below the median (and those with missing data) deemed Contract-Poor. This cut-off point was chosen because the life insurance data, when logged, form a strong bimodal distribution separated almost perfectly at the median. Since there are fewer nations near the median than elsewhere, it offers the most error-free cut-off point, given that we have no other reason to choose any other point in the scale. We then corroborated the systematic difference of the missing data from the known data with validity tests, which show that most nations with low levels of private consumption and investment - roughly reflecting a clientelist, or contract-poor economy - are not recorded in the life insurance data. ${ }^{57}$ We test our expected conditionality of the resource curse using the interaction term Energy Rents ${ }^{*}$ Contract-Poor. ${ }^{58}$

We also use additional controls to partial out our explanation from the existing democratization studies. The variable Income is the logarithm of gross domestic product (GDP) per capita. ${ }^{59}$ We consider the percentage of Muslim population in a country as of 2005 with the variable Muslim, ${ }^{60}$ Trade Openness measured as the logarithm of the fraction of sum of imports and exports in GDP, ${ }^{61}$ the logarithm of the country's Population, ${ }^{62}$ and Inequality measured as the share of capital in manufacturing value-added. ${ }^{63}$ Data for most variables were obtained using the EUGene data generation program. ${ }^{64}$ Summary statistics are presented in Table 1. 
Table 1. Summary statistics.

\begin{tabular}{|c|c|c|c|c|c|}
\hline Variable & $N$ & Mean & Std. Dev. & Min & Max \\
\hline Democracy & 4777 & 49.21 & 34.57 & 0 & 100 \\
\hline Energy Rents & 4344 & 0.65 & 1.07 & 0 & 5.02 \\
\hline Contract-Poor $(C P)$ & 4177 & 0.83 & 0.37 & 0 & 1 \\
\hline Energy Rents ${ }^{*} C P$ & 3708 & 0.61 & 1.06 & 0 & 5.02 \\
\hline GDP per Capita & 5049 & 8.25 & 1.08 & 5.64 & 10.74 \\
\hline Trade Openness & 4864 & -8.81 & 1.13 & -14.60 & -3.81 \\
\hline Population & 5049 & 8.62 & 1.92 & 2.89 & 14.05 \\
\hline Muslim & 4311 & 1.38 & 2.68 & -4.61 & 4.60 \\
\hline Inequality & 2961 & 58.27 & 11.50 & 30.04 & 84.89 \\
\hline Inequality $^{2}$ & 2961 & 3527.16 & 1337.03 & 902.30 & 7206.04 \\
\hline
\end{tabular}

\section{Estimation}

In accordance with the literature, we test our theory using different estimation techniques - ordinary least squares (OLS), within group estimator, and generalized method of moments (GMM). We utilize the following autoregressive distributed lag (ADL) specification to disentangle the conditionality of resource curse on the contract-intensity of a country:

$$
\begin{aligned}
d_{i t} & =a_{0}+\phi d_{i t-1}+\beta_{0} r_{i t}+\beta_{1} r_{i t-1}+\beta_{2} C P_{i t}+\beta_{3} C P_{i t-1}+\beta_{4} C P_{i t} r_{i t} \\
& +\beta_{5} C P_{i t-1} r_{i t-1}+\lambda \boldsymbol{x}_{i t}+\zeta \boldsymbol{x}_{i t-1}+\delta_{t}+u_{i, t}
\end{aligned}
$$

where $d_{i t}$ is the democracy score of a country $i$ in period $t, r_{i t}$ is the value of energy rents, $C P_{i t}$ is the dummy variable where one indicates that country $i$ in period $t$ has a contract-poor economy, $C P_{i t} r_{i t}$ is the multiplicative interaction term that is the main variable of interest, $\boldsymbol{x}_{i, t}$ is a vector of control variables, $\delta_{t}$ is the unobservable time-specific effect which captures common shocks to democracy for all countries, and $u_{i, t}=\eta_{i}+\varepsilon_{i t}$ is the disturbance term where $\eta_{i}$ is the unobservable countryspecific, time-invariant effect.

In the specification, the unobserved time-invariant individual effect $\eta_{i}$ is absorbed by the error term, which leads to the assumption that all the countries have the same preconditions for democratization. However, since $d_{i t-1}$ is by construction positively correlated with $\alpha_{i}$ the point estimates will be biased and inconsistent regardless of the sample size. This omitted variable bias indicates that the OLS estimator is biased upwards. The most common approach to address this concern is to transform the equation by expressing all variables as deviations from the mean values for each country through the within groups estimator. However, the transformed lagged dependent variable $\left(d_{i t-1}-\bar{d}_{i}\right)$ is negatively correlated with the transformed error term, which renders the within groups estimator downwardly biased. ${ }^{65}$ Nevertheless, the fact that the OLS and the within groups estimators are biased in the opposite directions is useful as they constitute the 
upper and lower bounds for a consistent estimator. ${ }^{66}$ System GMM provides much greater precision in estimates in the presence of highly persistent series by estimating the differenced and level equations simultaneously. ${ }^{67}$ Accordingly, we use system GMM as our preferred estimation technique to test the conditional impact of resource rents on democracy. Moreover, in all GMM analyses, we use two-step robust system GMM and apply Windmeijer correction, which render two-step robust system GMM estimations more efficient than one-step robust estimations. $^{68}$

\section{Results}

Table 2 reports the main empirical results of our dynamic specification analysing all countries over the period $1973-2000 .^{69}$ The first two columns show the results from pooled OLS and within-group estimators, respectively. Even though the coefficient estimates are not informative in these two specifications, they provide the upper and lower bounds of the autoregressive coefficient of democracy for a consistent estimator, respectively. ${ }^{70}$ Columns $3-5$ report the analyses from system GMM and proceed from the baseline resource curse model to our modified model to test the conditional impact of resource rents. The autoregressive coefficients of democracy in each column are within the lower and upper bounds $(0.84<\phi<0.96)$, informing us of the consistency of the estimates. Since we adopt a dynamic specification, we are able to use the wide array of the information available from this specification and estimate the short- and long-term effects of all right-hand side variables and their corresponding median and mean lengths. ${ }^{71}$ In the ADL specification, the short term effects of each variable are directly given by the point estimates of the coefficients for the current and previous periods. The point estimates of long-term effects for variable $k\left(\mathrm{LTE}_{k}\right)$ are calculated by the following adjustment:

$$
\mathrm{LTE}_{k}=\frac{\beta_{k}^{t}+\beta_{k}^{t-1}}{1-\phi}
$$

Column 3 reports the baseline model of the impact of resource rents on democracy. As expected, energy rents do not have an effect on democracy in the short term, and hence we focus on long term effects. The coefficient of energy rents is statistically significant and negative ( $\mathrm{LTE}_{\text {Energy Rents }}=-10.35, p<0.01$ ). In Column 4, we add the control for political economy type. We see that coefficient for Contract-Poor economy in the long term is negative and highly significant $\left(\mathrm{LTE}_{\text {Contract-Poor }}=-36.81, p<0.01\right)$, corroborating our expectation that clientelist economy is detrimental for democracy.

Model 5 tests the hypothesis that institutionalized patronage opportunities are an important precondition for the detrimental effects of resource rents on democracy, and nations with contract-intensive economies are immune from it. We test this conditional hypothesis with the interaction term Energy Rents*Contract 
Table 2. Conditional effect of resource rents on democracy.

\begin{tabular}{|c|c|c|c|c|c|}
\hline & $\begin{array}{c}\text { Model } 1 \\
\text { Pooled OLS }\end{array}$ & $\begin{array}{c}\text { Model } 2 \\
\text { Within Group }\end{array}$ & $\begin{array}{c}\text { Model } 3 \\
\text { System GMM }\end{array}$ & $\begin{array}{c}\text { Model } 4 \\
\text { System GMM }\end{array}$ & $\begin{array}{c}\text { Model } 5 \\
\text { System GMM }\end{array}$ \\
\hline $\begin{array}{l}\text { Democracy }_{t-1} \\
\text { Short Term Effects }\end{array}$ & $0.96^{* * *}(0.01)$ & $0.84^{* * *}(0.02)$ & $0.94^{* * *}(0.04)$ & $0.95^{* * *}(0.03)$ & $0.95^{* * *}(0.03)$ \\
\hline Contract Poor (CP) & $-1.36^{*}(0.72)$ & $-0.015(1.28)$ & & $-1.47(1.12)$ & $-1.51(1.14)$ \\
\hline Energy Rents & $-0.048(0.52)$ & $-0.34(0.63)$ & $-0.49(0.76)$ & $-0.22(0.76)$ & $-0.31(0.67)$ \\
\hline Energy Rents ${ }^{*} C P$ & $0.073(0.61)$ & $0.16(0.74)$ & & & $0.11(0.71)$ \\
\hline Contract Poor $_{t-1}$ & $-0.034(0.74)$ & $0.17(1.17)$ & & $-0.33(0.98)$ & $-0.16(1.01)$ \\
\hline Energy Rents $_{t-1}$ & $0.0087(0.52)$ & $-0.24(0.64)$ & $-0.10(0.72)$ & $-0.22(0.73)$ & $0.29(0.72)$ \\
\hline Energy Rents ${ }_{t-1} * C P_{t-1}$ & $-0.41(0.63)$ & $0.062(0.71)$ & & & $-0.55(0.74)$ \\
\hline $\begin{array}{l}\text { Long Term Effects } \\
\text { Energy Rents }\end{array}$ & - & & & & \\
\hline $\begin{array}{l}\text { Energy Rents } \\
\text { Energy Rents }(C P=0)\end{array}$ & $-0 . \overline{90}(5.75)$ & $\begin{array}{c}- \\
-3.66(5.20)\end{array}$ & $\begin{array}{c}-10.35^{* * *}(3.05) \\
\end{array}$ & $\begin{array}{c}-8.96^{* *}(3.66) \\
-\end{array}$ & $\begin{array}{c}- \\
-0.51(5.97)\end{array}$ \\
\hline Energy Rents $(C P=1)$ & $-8.46^{* * *}(2.68)$ & $-2.27(4.02)$ & - & - & $-9.33^{* *}(3.62)$ \\
\hline Contract-Poor & - & - & - & $-36.81^{* * *}(8.67)$ & - \\
\hline Constant & $4.00^{* * *}(1.01)$ & $7.45^{* * *}(1.63)$ & $3.91^{*}(2.26)$ & $4.67^{*}(2.47)$ & $4.62 *(2.41)$ \\
\hline Observations & 3320 & 3320 & 3340 & 3320 & 3320 \\
\hline \# of Countries & 150 & 150 & 152 & 150 & 150 \\
\hline \# of Instruments & - & - & 58 & 60 & 62 \\
\hline Collapsed IV Matrix & - & - & Yes & Yes & Yes \\
\hline $\operatorname{AR}(1)(p$-val) & - & - & 0.00 & 0.00 & 0.00 \\
\hline $\operatorname{AR}(2)(p$-val) & - & - & 0.87 & 0.80 & 0.80 \\
\hline Sargan & - & - & 0.80 & 0.73 & 0.73 \\
\hline Hansen & - & - & 0.55 & 0.42 & 0.43 \\
\hline Difference Hansen & - & - & 0.69 & 0.73 & 0.74 \\
\hline
\end{tabular}

Robust standard errors are in parentheses. Year dummies are included but not presented to save space. Standard errors of the long term effects are estimated using the delta method.

${ }^{*} p<0.10,{ }^{* *} p<0.05,{ }^{* * *} p<0.01$. 
Poor. Given that the model includes an interaction term, the coefficients as well as the standard errors of the multiplicative term are not illuminating on their own, and we have to calculate substantively meaningful marginal effects and standard errors for each specification. Following the practice suggested by Kam and Franzese, we report the effect of Energy Rents on democracy when $C P=1$ and $C P=0$ for all specifications. ${ }^{72}$ The first and second conditional short-run effects of Energy Rents are analytically calculated as:

$$
\begin{gathered}
\frac{\partial d_{i t}}{\partial r_{i t}}=\beta_{0}+\beta_{4} C P_{i t} \\
\frac{\partial d_{i t}}{\partial r_{i t-1}}=\beta_{1}+\beta_{4} C P_{i t-1}
\end{gathered}
$$

while the long term effect is calculated as:

$$
\frac{1}{1-\phi}\left(\frac{\partial d_{i t}}{\partial r_{i t}}+\frac{\partial d_{i t}}{\partial r_{i t-1}}\right)=\frac{\beta_{0}+\beta_{4} C P_{i t}+\beta_{1}+\beta_{4} C P_{i t-1}}{1-\phi}
$$

For contract-rich economies $\left(C P_{i t}=0\right.$ and $\left.C P_{i t-1}=0\right)$, the effect of Energy Rents is negative but statistically insignificant $\left(\mathrm{LTE}_{\text {Energy Rents }}=-0.51, p=\right.$ $0.93)$. In contrast, for contract-poor economies $\left(C P_{i t}=1\right.$ and $\left.C P_{i t-1}=1\right)$, the effect is negative and statistically significant $\left(L T E_{\text {Energy }}\right.$ Rents $=-9.33, p=$ $0.01) .^{73}$ Thus, results provide broad support for our hypothesis that the detrimental effect of natural resource rents on democracy is conditional on the prevailing economy type, and contract-rich countries are immune from the resource curse. Figure 1 presents the distribution of the marginal cumulative effect of Energy Rents on democracy for contract-poor countries over time.

Finally, Tables $3 \mathrm{a}$ and $\mathrm{b}$ introduce additional control variables from democratization studies to our main specification in Column 5 of Table 2, and Table $3 \mathrm{a}$ shows that the short-term effects are negligible, as expected. The corresponding long term effects are presented in Table $3 \mathrm{~b}$. Across all specifications the long term effects of Energy Rents on democracy are statistically insignificant for



Figure 1. Marginal cumulative effect of energy rents on democracy for contract-poor countries. 
Table 3. Conditional effect of resource rents on democracy with additional controls.

\begin{tabular}{|c|c|c|c|c|c|c|}
\hline \multicolumn{7}{|l|}{ a Short Term Effects } \\
\hline & $\begin{array}{c}\text { Model } 1 \\
\text { System GMM }\end{array}$ & $\begin{array}{c}\text { Model } 2 \\
\text { System GMM }\end{array}$ & $\begin{array}{c}\text { Model } 3 \\
\text { System GMM }\end{array}$ & $\begin{array}{c}\text { Model } 4 \\
\text { System } G M M\end{array}$ & $\begin{array}{c}\text { Model } 5 \\
\text { System GMM }\end{array}$ & $\begin{array}{c}\text { Model } 6 \\
\text { System GMM }\end{array}$ \\
\hline Democracy $_{t-1}$ & $0.94^{* * *}(0.03)$ & $0.94^{* * *}(0.03)$ & $0.94^{* * *}(0.03)$ & $0.95^{* * *}(0.03)$ & $0.94^{* * *}(0.03)$ & $0.93^{* * *}(0.03)$ \\
\hline Contract Poor & $-0.37(0.86)$ & $-1.32(1.05)$ & $-1.74(1.18)$ & $-1.23(1.14)$ & $-2.33(1.40)$ & $-0.70(1.10)$ \\
\hline Energy Rents & $-0.28(0.65)$ & $-0.44(0.67)$ & $-0.34(0.67)$ & $-0.24(0.68)$ & $0.39(0.77)$ & $0.50(0.77)$ \\
\hline Energy Rents ${ }^{*} \mathrm{CP}$ & $-0.0058(0.70)$ & $0.055(0.73)$ & $0.047(0.71)$ & $0.020(0.71)$ & $-1.32(0.99)$ & $-1.69(1.05)$ \\
\hline Contract Poor ${ }_{t-1}$ & $0.57(0.92)$ & $-0.31(1.00)$ & $-0.31(1.03)$ & $-0.12(1.00)$ & $0.19(1.29)$ & $1.21(1.15)$ \\
\hline Energy Rents Rel $_{t}$ & $0.23(0.69)$ & $0.43(0.68)$ & $0.32(0.71)$ & $0.33(0.75)$ & $-0.28(0.86)$ & $-0.23(0.88)$ \\
\hline Energy Rents $_{t-1}{ }^{*} C P_{t-1}$ & $-0.76(0.75)$ & $-0.60(0.73)$ & $-0.52(0.74)$ & $-0.45(0.77)$ & $0.81(1.04)$ & $0.73(1.09)$ \\
\hline Income & $4.08(2.88)$ & & & & & $4.39(4.81)$ \\
\hline Income $_{t-1}$ & $-2.93(2.82)$ & & & & & $-3.23(4.72)$ \\
\hline Trade Openness & & $1.02(0.94)$ & & & & $0.57(1.17)$ \\
\hline Trade Openness ${ }_{t-1}$ & & $-0.79(0.91)$ & & & & $-0.32(1.09)$ \\
\hline Population & & & $-12.0(20.95)$ & & & $-20.4(31.15)$ \\
\hline Population $_{t-1}$ & & & $12.1(20.92)$ & & & $20.5(31.15)$ \\
\hline Muslim & & & & $-0.27^{* *}(0.12)$ & & $-0.27^{*}(0.14)$ \\
\hline Inequality & & & & & $0.76(0.54)$ & $0.75(0.54)$ \\
\hline Inequality $^{2}$ & & & & & $-0.01(0.00)$ & $-0.01(0.00)$ \\
\hline Inequality $_{t-1}$ & & & & & $-0.71(0.57)$ & $-0.68(0.59)$ \\
\hline Inequality $_{t-1}^{2}$ & & & & & $0.01(0.01)$ & $-0.01(0.01)$ \\
\hline Constant & $-5.86^{* *}(2.73)$ & $6.92 *(3.91)$ & $5.39^{*}(3.01)$ & $4.60^{*}(2.60)$ & $4.32(4.45)$ & $-5.28(7.84)$ \\
\hline Observations & 3317 & 3244 & 3317 & 3216 & 2394 & 2295 \\
\hline \# of Countries & 150 & 146 & 150 & 145 & 114 & 107 \\
\hline \# of Instruments & 64 & 64 & 64 & 63 & 66 & 73 \\
\hline $\operatorname{AR}(1)(p$-val) & 00.0 & 0.00 & 0.00 & 0.00 & 0.00 & 0.00 \\
\hline $\operatorname{AR}(2)(p$-val) & 0.80 & 0.81 & 0.83 & 0.60 & 0.90 & 0.95 \\
\hline Sargan & 0.81 & 0.81 & 0.79 & 0.57 & 0.94 & 0.94 \\
\hline Hansen & 0.48 & 0.41 & 0.45 & 0.49 & 0.30 & 0.36 \\
\hline Diff Hansen & 0.95 & 0.61 & 0.95 & 0.99 & 0.76 & 0.75 \\
\hline
\end{tabular}


Table 3. Continued

\begin{tabular}{|c|c|c|c|c|c|c|}
\hline \multicolumn{7}{|l|}{ b Long Term Effects } \\
\hline & $\begin{array}{c}\text { Model } 1 \\
\text { System GMM }\end{array}$ & $\begin{array}{c}\text { Model } 2 \\
\text { System GMM }\end{array}$ & $\begin{array}{c}\text { Model } 3 \\
\text { System GMM }\end{array}$ & $\begin{array}{c}\text { Model } 4 \\
\text { System GMM }\end{array}$ & $\begin{array}{c}\text { Model } 5 \\
\text { System GMM }\end{array}$ & $\begin{array}{c}\text { Model } 6 \\
\text { System GMM }\end{array}$ \\
\hline Energy Rents $(C P=0)$ & $-0.841(4.92)$ & $-0.152(5.78)$ & $-0.394(5.18)$ & $1.80(5.38)$ & $1.80(5.80)$ & $3.66(4.72)$ \\
\hline Energy Rents $(C P=1)$ & $-13.74^{* * *}(3.32)$ & $-9.71^{* * *}(3.21)$ & $-8.19^{* * *}(3.11)$ & $-7.26^{* *}(3.49)$ & $-6.78^{*}(3.54)$ & $-9.49^{* * *}(2.98)$ \\
\hline Income & $19.36^{* * *}(3.34)$ & & & & & $15.85^{* * *}(5.80)$ \\
\hline Trade Openness & & $4.03(3.53)$ & & & & $3.43(5.06)$ \\
\hline Population & & & $0.480(1.71)$ & & & $0.88(2.25)$ \\
\hline Muslim & & & & $-5.61^{* * *}(1.30)$ & & $-3.68^{* * *}(0.84)$ \\
\hline Inequality & & & & & $0.82(1.88)$ & $1.04(1.80)$ \\
\hline Inequality ${ }^{2}+$ & & & & & $-0.01(0.02)$ & $-0.01(0.02)$ \\
\hline Observations & 3317 & 3244 & 3317 & 3216 & 2394 & 2295 \\
\hline \# of Countries & 150 & 146 & 150 & 145 & 114 & 107 \\
\hline \# of Instruments & 64 & 64 & 64 & 63 & 66 & 73 \\
\hline Collapsed IV Matrix & Yes & Yes & Yes & Yes & Yes & Yes \\
\hline $\operatorname{AR}(1)(p$-val $)$ & 0.00 & 0.00 & 0.00 & 0.00 & 0.00 & 0.00 \\
\hline $\operatorname{AR}(2)(p$-val $)$ & 0.80 & 0.81 & 0.83 & 0.60 & 0.90 & 0.95 \\
\hline Sargan & 0.81 & 0.81 & 0.79 & 0.57 & 0.94 & 0.94 \\
\hline Hansen & 0.48 & 0.41 & 0.45 & 0.49 & 0.30 & 0.36 \\
\hline Diff Hansen & 0.95 & 0.61 & 0.95 & 0.99 & 0.76 & 0.75 \\
\hline
\end{tabular}

Standard errors in parentheses. Year dummies are included but not presented to save space. Muslim $t_{t-1}$ is dropped due to collinearity. Instrument Matrix is collapsed to correct for the instrument proliferation. ${ }^{*} p<0.10,{ }^{* *} p<0.05,{ }^{* * *} p<0.01$.

Standard errors of the long term effects are estimated using the delta method, short-run coefficient estimates of which are presented in Table 3 a. ${ }^{*} p<0.10$, ${ }^{* *} p<0.05,{ }^{* * *} p<0.01$. $\$$ For space constraints, we do not present Inequality and Inequality's substantively meaningful values. 
contract-rich economies but negative and statistically significant for contract-poor economies, again providing strong evidence for our hypothesis. Among the additional controls considered, only the variables Income and Muslim have statistically significant long term effects on democracy.

\section{Conclusion}

We began this study recognizing that while the negative impact of natural resource dependence on democracy is widely and rightly accepted as an accurate observation, existing theories cannot explain why some countries have been immune to it. We have sought to address this puzzle by drawing insights from economic norms theory. ${ }^{74}$ When a contract-intensive society becomes endowed with resource rents, prevailing norms of impartiality and respect for the rule of law ensure that the new-found wealth is distributed to citizens largely impartially and transparently, and the resource rents have no negative repercussions on democratic institutions. In modern economies the predominantly alternative form of economic integration is clientelism, where individuals normally rely on patrons for physical and economic securities in exchange for political support. When a clientelist political economy becomes endowed with resource rents, the prevailing culture of clientelism causes a regime to distribute the rents with partiality in exchange for support. As a result, the prospect for democracy is undermined, and the power of the regime solidified. Analyses herein of most countries from 1973 to 2000 yields substantial additional support for our hypothesis: resource rents are detrimental for democracy only in nations with contract-poor economies. For nations with contract-rich economies, resource rents have no discernible impact on governing institutions.

There are four major implications of this study. First, we have offered an important qualification to rentier state theory: a necessary condition for a rentier state is a contract-poor, clientelist political economy. Second, numerous studies have confirmed a linkage of wealth with democracy, but there is little consensus on how wealth causes democracy. The economic norms explanation informs us that the answer may lie in contract-intensive economy and its culture of contracting, which may cause both advanced economy and democracy. Third, this study has direct implications for grasping the Middle East, a region rife with resource rent dependence, autocracy, and conflict. We have shown how one factor - the contract-poor norms of clientelism that are known to corrupt most governments in the region ${ }^{75}$ - may substantially account for all three of these patterns.

Finally, in contrast to prior explanations for the resource curse, the economic norms explanation offers an antidote for it: immunity from the resource curse of conflict and dictatorship is achieved when most citizens in a nation can normally find jobs and feed their families in the marketplace rather than through connections with rent-seeking groups. A pro-democracy regime in a resource-rich country is advised to use the resource rents to promote the public good of market growth, including equal access in the marketplace, over the politically-safe alternative of 
distributing private goods for political support. The task for the international community seeking to reduce global tensions could hardly be clearer: the oil-importing nations must substantially reduce their dependence on oil. In this way, the price of oil may drop and the "First Law of Petropolitics" can be broken, ${ }^{76}$ giving democracy and peace a chance to take root in the Middle East and in other oil exporting regions.

\section{Acknowledgements}

All authors contributed equally to this work.

\section{Notes}

1. Mahdavy, "The Patterns and Problems of Economic Development."

2. Haber and Menaldo, "Do Natural Resources Fuel Authoritarianism?"

3. Goldberg, Wibbels, and Mvukiyehe, "Lessons from Strange Cases."

4. Ibid., 479.

5. Dunning, Crude Democracy.

6. Ross, "Oil and Democracy Revisited," 25.

7. This article builds on Aytaç, "Why Are Some Countries Immune."

8. Mousseau, "Market Prosperity, Democratic Consolidation, and Democratic Peace"; Mousseau, "The Social Market Roots of Democratic Peace"; Güneş-Ayata, "Clientelism"; Roniger, "The Comparative Study of Clientelism."

9. Mousseau, "Capitalist Development and Civil War."

10. We use the terms cilentelist/contract-poor and contractualist/contract-intensive interchangeably.

11. Early influential studies on the impact of resource wealth on economic development include Gelb, Oil Windfalls and Auty, Sustaining Development in the Mineral Economies. A comprehensive review of this literature is presented by Ross, "The Political Economy of the Resource Curse" and a more recent review is by van der Ploeg, "Natural Resources." A different strand of the literature focuses on the relationship between resource wealth and conflict; for a review of this literature see Ross, "What Do We Know About Natural Resources?"

12. Ross, "Does Oil Hinder Democracy?" 356.

13. Jensen and Wantchekon, "Resource Wealth and Political Regimes"; Smith, "Oil Wealth and Regime Survival"; Ulfelder, "Natural-Resource Wealth and Survival"; Aslaksen, "Oil and Democracy"; Ramsay, "Revisiting the Resource Curse"; compare with Herb, "No Representation without Taxation?"

14. Dunning, Crude Democracy.

15. Haber and Menaldo, "Do Natural Resources Fuel Authoritarianism?" Thus the authors favor a fixed effects specification.

16. Andersen and Ross, "The Big Oil Change."

17. Ross, "Does Oil Hinder Democracy?"

18. Goldberg, Wibbels, and Mvukiyehe, "Lessons from Strange Cases," 479; Ross, "Does Oil Hinder Democracy?" 343-4; Herb, "No Representation without Taxation?" 8; Ulfelder, "Natural-Resource Wealth and Survival," 999.

19. Central Intelligence Agency, The World Factbook 2012.

20. Goldberg, Wibbels, and Mvukiyehe, "Lessons from Strange Cases."

21. Dunning, Crude Democracy.

22. Mauss, Gift; Polanyi, The Great Transformation. 
23. Güneş-Ayata, "Clientelism"; Roniger, "The Comparative Study of Clientelism."

24. Güneş-Ayata, "Clientelism," 20-1.

25. Mousseau, "Capitalist Development and Civil War." The contract intensity of a society should not be confused with familiar notions of economic freedom or contract enforcement (see Clague et al., "Contract-intensive Money").

26. Mousseau, "The Social Market Roots of Democratic Peace," 58-62.

27. We use the "Freedom in the World" dataset of the Freedom House to measure the political regime type, and by "major democratic reversal" we mean a move from a "Free" status to "Partly Free" or "Not Free."

28. Ross, The Oil Curse.

29. Norway and Russia are different in many aspects beyond contract-intensity of their economies, and we do not claim that the theory we propose is the only explanation for the divergent political trajectories of the two countries. Rather than attributing causality, the comparison is intended to be illustrative of the different mechanisms that we think are at work in a contract-rich versus contract-poor economy regarding how natural resource rents are managed.

30. Central Intelligence Agency, The World Factbook 2012.

31. Mousseau, "The Social Market Roots of Democratic Peace." A highly interventionist state, such as Norway's, does not preclude a contract-intensive economy.

32. Mehlum, Moene, and Torvik, "Mineral Rents and Social Development in Norway."

33. Eifert, Gelb, and Tallroth, "The Political Economy of Fiscal Policy."

34. Ibid., 8 .

35. Central Intelligence Agency, The World Factbook 2012.

36. OECD, OECD Economic Surveys.

37. Fish, Democracy Derailed in Russia.

38. Way, "Authoritarian State Building."

39. Freedom House, Freedom in the World.

40. Remington, "Patronage and the Party of Power."

41. OECD, OECD Economic Surveys.

42. Remington, "Patronage and the Party of Power."

43. Fish, Democracy Derailed in Russia.

44. Ibid., 127.

45. Transparency International, Corruption Perception Index 2012.

46. OECD, OECD Economic Surveys, 77.

47. Fish, Democracy Derailed in Russia.

48. Ibid., 187-92.

49. Freedom House, Freedom in the World. Replication materials for the analysis are available at http://thedata.harvard.edu/dvn/dv/orsun.

50. We prefer using Freedom House data instead of Polity IV due to precision, reliability, and validity concerns associated with the latter. For a detailed overview of these concerns with Polity IV data, see Gleditsch and Ward, "Double Take"; Munck and Verkuilen, "Conceptualizing and Measuring Democracy"; Treier and Jackman, "Democracy as a Latent Variable." Nevertheless, we replicate our analyses with Polity IV data, and there is no substantial change in the results, which are available upon request.

51. World Bank, The Changing Wealth of Nations.

52. We prefer a measure of resource wealth relative to GNI rather than a per-capita measure, because while the former can capture the relative importance of resource wealth for the economy, the latter cannot. Nevertheless, we use Aike Information Criterion (AIC) to test how good the fit is across the two measures. Results indicate that the measure of energy rents as of GNI outperforms $(\mathrm{AIC}=13,726.6)$ the specification with measure of energy rents per capita $(\mathrm{AIC}=13,841.7)$. 
53. Haber and Menaldo, "Do Natural Resources Fuel Authoritarianism?"; Andersen and Ross, "The Big Oil Change."

54. Karl, "The Perils of the Petro-State," 36.

55. Mousseau, "Capitalist Development and Civil War"; Mousseau and Mousseau, "The Contracting Roots of Human Rights"; Mousseau, "The Social Market Roots of Democratic Peace." Clague et al. (1999) develop the measure "Contract-intensive Money", the proportion of currency in banks, and offer it as a measure of trust in government enforcement of contracts under the assumption that money in banks is less safe where government does not reliably enforce contracts. This is not a direct measure of thirdparty-dependent contracting, and is noisy because it assumes that there is a substitute for holding money in banks, whereas in a clientelist economy the weak nature of the state and the lax respect for property rights can often render bank deposits the least risky of all alternatives.

56. Beck and Webb, "Economic, Demographic, and Institutional Determinants."

57. Heston, Summers, and Aten, Penn World Table Version 6.1.

58. All analyses were also carried out using the original and imputed data, with identical results obtained. We report the regressions using the dichotomous measure because it yields stronger results, suggesting that the binary measure is superior to the continuous one in analyses of democratization. With interaction terms a binary measure is also far easier to interpret than a continuous one.

59. Gleditsch, "Expanded Trade and GDP Data."

60. World Christian Database.

61. Barbieri and Keshk, Correlates of War Project.

62. Gleditsch, "Expanded Trade and GDP Data."

63. Dunning, Crude Democracy.

64. Bennett and Stam, "EUGene."

65. Nickell, "Biases in Dynamic Models with Fixed Effects."

66. Bond, "Dynamic Panel Data Models."

67. Blundell and Bond, "Initial Conditions and Moment Restrictions."

68. Windmeijer, "A Finite Sample Correction."

69. The Freedom House dataset we use covers 191 countries and after listwise deletion of some cases due to missing data, we are left with 150 countries in our main specification. 27 of the 41 excluded countries $(67 \%)$ are "microstates" with a population below 500,000 as of 2013. In addition, replicating the analyses with multiple imputation to the missing data produces substantively identical results to what we report.

70. Bond, "Dynamic Panel Data Models."

71. De Boef and Keele, "Taking Time Seriously."

72. Kam and Franzese, "Modeling and Interpreting Interactive Hypotheses."

73. Ross, The Oil Curse, and Andersen and Ross, "The Big Oil Change," report that the resource course has manifested itself only after the wave of nationalizations in the 1970s. To consider this possibility, we ran a separate identical analysis with a post1980 sample. The long term effect of energy rents in contract-poor countries is even stronger in the post- 1980 period (LTE Energy Rents $=-10.35, p=0.02)$. Moreover, we conducted analyses with cumulative lags up to five years as well, and there is no substantive change in the results. Analyses with different lag specifications are available upon request.

74. Mousseau, "Market Prosperity, Democratic Consolidation, and Democratic Peace."

75. Hamzeh, "Clientalism, Lebanon."

76. Friedman, "The First Law of Petropolitics." Thomas Friedman popularized the political resource curse with an influential article in Foreign Policy. He postulated the observation that "the price of oil and pace of freedom always move in opposite directions in oil-rich petrolist states" as the "First Law of Petropolitics." 


\section{Notes on contributors}

$\mathrm{S}$. Erdem Aytaç is a $\mathrm{PhD}$ candidate in the Department of Political Science at Yale University, USA. His research focuses on comparative political behaviour, economic voting, and the electoral politics of developing democracies. His previous work has been published or is forthcoming in Comparative Political Studies, Comparative Politics, and European Political Science Review.

Michael Mousseau (PhD Binghamton University 1998) is Professor of Political Science at the University of Central Florida, USA. His research is on the political economy of values and institutions and the implications for conflict within and among nations. Recent articles have appeared in International Security, International Studies Quarterly, and the Journal of Peace Research.

Ömer Faruk Örsün is a $\mathrm{PhD}$ candidate at Koç University, Turkey, and Pre-Doctoral Research Fellow at Department of Government, Harvard University, USA. His research broadly pursues an analytical synthesis of various approaches in international security, political economy, and comparative politics, and focuses on interstate conflicts, defence spending, foreign aid effectiveness and allocation, foreign policy cooperation and resource curse.

\section{Bibliography}

Andersen, Jorgen J., and Michael L. Ross. "The Big Oil Change: A Closer Look at the Haber-Menaldo Analysis." Comparative Political Studies 47, no. 7 (2014): 9931021.

Aslaksen, Silje. "Oil and Democracy: More Than a Cross-country Correlation?" Journal of Peace Research 47, no. 4 (2010): 421-431.

Auty, Richard M. Sustaining Development in the Mineral Economies: The Resource Curse Thesis. London: Routledge, 1993.

Aytaç, S. Erdem. "Why Are Some Countries Immune to the Negative Political Effects of Natural Resource Wealth: An Empirical Analysis.” M.A. thesis, Koç University, 2009.

Barbieri, Katherine, and Omar Keshk. Correlates of War Project Trade Data Set Codebook, Version 3.0, 2012. http://correlatesofwar.org.

Beck, Thorsten, and Ian Webb. "Economic, Demographic, and Institutional Determinants of Life Insurance Consumption across Countries." The World Bank Economic Review 17, no. 1 (2003): 51-88.

Bennett, Scott D., and Allan C. Stam. "EUGene: A Conceptual Manual." International Interactions 26, no. 2 (2000): 179-204.

Blundell, Richard, and Stephen Bond. "Initial Conditions and Moment Restrictions in Dynamic Panel Data Models." Journal of Econometrics 87, no. 1 (1998): 115-143.

Bond, Stephen R. "Dynamic Panel Data Models: A Guide to Micro Data Methods and Practice." Portuguese Economic Journal 1, no. 2 (2002): 141-162.

Central Intelligence Agency (CIA). The World Factbook 2012. Norway and Russia. Updated December 5, 2012, Retrieved December 22, 2012, from https://www.cia.gov/library/ publications/the-world-factbook/

Clague, Christopher, Philip Keefer, Stephen Knack, and Mancur Olson. "Contract-intensive Money: Contract Enforcement, Property Rights, and Economic Performance.” Journal of Economic Growth 4, no. 2 (1999): 185-211.

De Boef, Suzanna, and Luke Keele. "Taking Time Seriously.” American Journal of Political Science 52, no. 1 (2008): 184-200.

Dunning, Thad. Crude Democracy: Natural Resource Wealth and Political Regimes. New York: Cambridge University Press, 2008. 
Eifert, Benn, Alan Gelb, and Nils B. Tallroth. "The Political Economy of Fiscal Policy and Economic Management in Oil Exporting Countries.” Policy Research Working Paper No. 2899, World Bank, 2002.

Fish, M. Steven. Democracy Derailed in Russia: The Failure of Open Politics. New York: Cambridge University Press, 2005.

Freedom House. Freedom in the World. Westport, CT: Greenwood Press, 2012.

Friedman, Thomas L. "The First Law of Petropolitics." Foreign Policy 154 (2006): 28-36. Gelb, Alan, ed. Oil Windfalls: Blessing or Curse? New York: Oxford University Press, 1988.

Gleditsch, Kristian S. "Expanded Trade and GDP Data." Journal of Conflict Resolution 46, no. 5 (2002): $712-724$.

Gleditsch, Kristian S., and Michael D. Ward. "Double Take: A Reexamination of Democracy and Autocracy in Modern Polities." Journal of Conflict Resolution 41, no. 3 (1997): 361-383.

Goldberg, Ellis, Erik Wibbels, and Eric Mvukiyehe. "Lessons from Strange Cases: Democracy, Development, and the Resource Curse in the US States." Comparative Political Studies 41, no. 4-5 (2008): 477-514.

Güneş-Ayata, Ayşe. "Clientelism: Premodern, Modern, Postmodern." In Democracy, Clientelism, and Civil Society, edited by Luis Roniger and Ayşe Güneş-Ayata, 19-28. London: Lynne Rienner Publishers, 1994.

Haber, Stephen, and Victor Menaldo. "Do Natural Resources Fuel Authoritarianism? A Reappraisal of the Resource Curse." American Political Science Review 105, no. 1 (2011): $1-26$.

Hamzeh, A. Nizar. "Clientalism, Lebanon: Roots and Trends." Middle Eastern Studies 37, no. 3 (2001): 167-178.

Herb, Michael. "No Representation without Taxation? Rents, Development, and Democracy." Comparative Politics 37, no. 3 (2005): 297-316.

Heston, Alan, Robert Summers, and Bettina Aten. Penn World Table Version 6.1. Center for International Comparisons at the University of Pennsylvania, 2002.

Jensen, Nathan, and Leonard Wantchekon. "Resource Wealth and Political Regimes in Africa." Comparative Political Studies 37, no. 7 (2004): 816-841.

Kam, Cindy, and Robert Franzese. "Modeling and Interpreting Interactive Hypotheses in Regression Analysis: A Brief Refresher and Some Practical Advice." Unpublished manuscript, University of Michigan, 2003.

Karl, Terry L. "The Perils of the Petro-State: Reflections on the Paradox of Plenty." Journal of International Affairs 53, no. 1 (1999): 31-48.

Mahdavy, Hussein. "The Patterns and Problems of Economic Development in Rentier States: The Case of Iran." In Studies in Economic History of the Middle East, edited by Michael Allan Cook, 428-467. London: Oxford University Press, 1970.

Mauss, Marcel. Gift: The Form and Reason for Exchange in Archaic Societies. Paris: Presses Universitaries de France, 1950. Reprinted with translation by W. D. Halls. New York: W. W. Norton, 2000.

Mehlum, Halvor, Karl Moene, and Ragnar Torvik. "Mineral Rents and Social Development in Norway." Mimeo, Geneva, UNRISD workshop on Social Policy in Mineral-Rich Countries, 24-25 April, 2008.

Mousseau, Michael. "Market Prosperity, Democratic Consolidation, and Democratic Peace." Journal of Conflict Resolution 44, no. 4 (2000): 472-507.

Mousseau, Michael. "Capitalist Development and Civil War." International Studies Quarterly 56, no. 3 (2012): 470-483.

Mousseau, Michael. "The Social Market Roots of Democratic Peace." International Security 33, no. 4 (2009): 52-86.

Mousseau, Michael, and Demet Y. Mousseau. "The Contracting Roots of Human Rights." Journal of Peace Research 45, no. 3 (2008): 327-344. 
Munck, Gerardo L., and Jay Verkuilen. "Conceptualizing and Measuring Democracy: Evaluating Alternative Indices." Comparative Political Studies 35, no. 1 (2002): 5-34.

Nickell, Stephen. "Biases in Dynamic Models with Fixed Effects." Econometrica 49, no. 6 (1981): 1417-1426.

OECD. OECD Economic Surveys: Russian Federation 2011. Paris: OECD Publishing, 2011. http://dx.doi.org/10.1787/eco_surveys-rus-2011-en

Polanyi, Karl. The Great Transformation: The Political and Economic Origins of Our Time. New York: Farrar \& Rinehart, 1944. Reprint, Boston: Beacon Press, 1957.

Ramsay, Kristopher W. "Revisiting the Resource Curse: Natural Disasters, the Price of Oil, and Democracy." International Organization 65, no. 3 (2011): 507-529.

Remington, Thomas. "Patronage and the Party of Power: President - Parliament Relations Under Vladimir Putin." Europe - Asia Studies 60, no. 6 (2008): 959-987.

Roniger, Luis. "The Comparative Study of Clientelism and the Changing Nature of Civil Society in the Contemporary World." In Democracy, Clientelism, and Civil Society, edited by Luis Roniger and Ayşe Güneş-Ayata, 1-18. London: Lynne Rienner Publishers, 1994.

Ross, Michael L. "Does Oil Hinder Democracy?” World Politics 53, no. 3 (2001): 325-361.

Ross, Michael L. "Oil and Democracy Revisited." Unpublished manuscript, University of California-Los Angeles, 2009.

Ross, Michael L. The Oil Curse: How Petroleum Wealth Shapes the Development of Nations. Princeton, NJ: Princeton University Press, 2012.

Ross, Michael L. "The Political Economy of the Resource Curse." World Politics 51, no. 2 (1999): 297-322.

Ross, Michael L. "What Do We Know About Natural Resources and Civil War?” Journal of Peace Research 41, no. 3 (2004): 337-356.

Smith, Benjamin. "Oil Wealth and Regime Survival in the Developing World, 1960-1999." American Journal of Political Science 48, no. 2 (2004): 232-246.

Transparency International. Corruption Perceptions Index 2012. Retrieved November 2013, from http://www.transparency.org/cpi2012/results

Treier, Shawn, and Simon Jackman. "Democracy as a Latent Variable." American Journal of Political Science 52, no. 1 (2008): 201-217.

Ulfelder, Jay. "Natural-Resource Wealth and the Survival of Autocracy." Comparative Political Studies 40, no. 8 (2007): 995-1018.

van der Ploeg, Frederick. "Natural Resources: Curse or Blessing?” Journal of Economic Literature 49, no. 2 (2011): 366-420.

Way, Lucan A. "Authoritarian State Building and the Sources of Regime Competitiveness in the Fourth Wave: The Cases of Belarus, Moldova, Russia, and Ukraine." World Politics 57, no. 2 (2005): 231-261.

Windmeijer, Frank. "A Finite Sample Correction for the Variance of Linear Efficient Twostep GMM Estimators." Journal of econometrics 126, no. 1 (2005): 25-51.

World Bank. The Changing Wealth of Nations: Measuring Sustainable Development in the New Millennium. Washington, DC: World Bank Publications, 2010.

World Christian Database. Accessed November 15, 2012. http://worldchristiandatabase.org/ wed 